\title{
Robust Design of Spaghetti Products based on Consumer Needs
}

\author{
Nur Kartika Indah Mayasti ${ }^{a *}$, Mirwan Ushada ${ }^{b}$, Makmudun Ainuri ${ }^{b}$ \\ a Peneliti Pusat Penelitian Teknologi Tepat Guna, Indonesia \\ Jl. K.S Tubun no. 5 Subang, Jawa Barat, 41213, Indonesia \\ b Jurusan Teknologi Industri Pertanian, Fakultas Teknologi Pertanian, Universitas Gadjah Mada, Indonesia \\ Jl. Flora, Bulaksumur, Caturtunggal, Sleman, D.I. Yogyakarta, 55281, Indonesia \\ * Corresponding author: indahmayasti@gmail.com
}

\section{ARTICLE INFO}

Article history

Received September 24, 2019

Revised August 3, 2020

Accepted August 7, 2020

Available Online August 30, 2020

Keywords

Product concept

Composite spaghetti

Robust Product

Consumer requirement

Orthogonal Taguchi

\section{ABSTRACT}

To produce competitive advantage, a product has to be designed according to the criteria of consumer needs. The results of identifying consumer needs become technical requirements and target specifications in robust product design. The purpose of this research was to propose a robust design of gluten-free spaghetti product concept using the Taguchi method. The selection of factors and experimental levels utilized the zero one matrix and the evaluation matrix. The results showed that the priority quality attributes required by consumers include good product display, nutrition, acceptable taste, competitive prices, and made from local ingredients. Product specifications that are targeted at product quality are closer to commercial spaghetti products. Based on the experimental design, four factors and three levels with an orthogonal matrix (Taguchi) L9 (34) resulted in 9 product concepts. The selected concept has confirmed the quality of its spaghetti products.

This is an open-access article under the CC-BY-SA license.

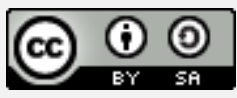

\section{Introduction}

Spaghetti is a popular type of pasta product [1]. Pasta products have been globalized and become the staple food of European countries and other countries as well. Along with the high market demand, spaghetti products are developed in various variants, including gluten-free, organic, high fiber, fortified, even low carbohydrate content. The emergence of gluten-free spaghetti products is due to product innovation and consumer demand allergic to gluten. Spaghetti products made from durum flour (semolina) are not recommended [2]. In this problem, product design is tailored to customer needs through market research and customer feedback by incorporating technological elements. Product design refers to product quality to face business competition. Product development consists of several stages that consider economic aspects and benchmarking against competitors' products to gain competitive advantage [3].

In product development, an aspect that is no less important than product innovation is the ability to read dynamic market needs [4]. To produce a competitive 
advantage in designing a product, it is necessary to identify the quality attributes of market needs. Previous studies that are similar to the research conducted include the application of value engineering in the selection of packaging design and taste of products using weighting methods, morphological analysis, and Zero-One analysis [5]. The Taguchi method was also proposed for robust parameter design based on orthogonal array matrices. The Taguchi method was utilized for product design in carrot sweets [6].

In several previous studies, the development of gluten-free spaghetti products was more focused on process engineering to produce a product quality similar to wheat spaghetti. However, the quality of the gluten-free spaghetti pasta product has not been able to match the wheat pasta on the market [7]. Consumers want spaghetti products that are not sticky, not easily brittle, and have low cooking loss [8]. Gluten-free pasta products have cooking loss 2-4 times higher than wheat pasta [9] [2] [10]. Gluten is the main determining factor in the cooking quality of pasta products [11]. The manufacture of gluten-free spaghetti relies on gelatinized starch and a retro-gradation mechanism for optimal dough formation. The manufacturing process uses an extrusion technique with an extruder machine [12] [13]. In terms of nutritional content, gluten-free spaghetti products are deficient in dietary fiber and other important nutrients, such as minerals and vitamins [14]. The fortification of nutritious ingredients rich in protein and gluten-free dietary fiber is expected to improve the nutrition of gluten-free pasta products [15].

The preparation or making of spaghetti is enriched with fiber-enhancing ingredients and other nutrients to improve nutrition and texture closer to wheat pasta [16] [17] [13]. Another study discusses the making of gluten-free spaghetti from rice flour with $5.0 \%$ soy protein isolate, which can reduce cooking time and cooking loss [1]. The addition of soy flour to increase protein in the manufacture of composite spaghetti with a single screew extruder machine increases the protein content and hedonic sensory tests of aroma, taste, hardness, stickiness, and overall acceptance that are somewhat favored [10]. From this research, the resulting cooking loss of spaghetti was still relatively high. Further research to improve the quality of gluten-free spaghetti from composite flour resulted in a cooking loss of $5.95 \%$, which is not significantly different from wheat spaghetti on the market of $6.01 \%$ but with a higher stickiness level [18].

Based on the description above, research on the design of gluten-free spaghetti products has received much attention from researchers. Unfortunately, previous studies have not considered consumer needs as a basis for product design. This study is intended to design a gluten-free spaghetti product concept based on the quality attributes desired by consumers. The optimization design for robust product design uses the Taguchi method. The Taguchi method is efficient because it makes it possible to carry out research that involves many factors and levels. The experimental design using the Taguchi method can produce products and robust processes against uncontrolled factors [10]. Several research methods related to product design include value engineering, Taguchi method, concurrent engineering, canoe models, as well as quality and function deployment [2] [19] [20]. The benefit of this research is to enrich knowledge related to product design and development research starting from the beginning. The stages include identifying consumer needs and determining experimental factors, and optimizing many experimental factors with the Taguchi method. The results of this study are expected to produce a robust design concept for gluten-free spaghetti products.

This paper consisted of several sections consisting of methods, data collection, and proposed methods are located in section 2 . The results and discussion are presented in section 3 , while the conclusions are written in section 4 . 


\section{Methods}

\subsection{Proposed Procedure}

\subsubsection{Identification of Consumer Needs}

Several procedures were carried out at this stage, including the content validity ratio, the measurement of validity and reliability of the questionnaire, the identification of quality attributes of consumer needs, and the selection of alternative experimental factors.

At the initial stage, the content validity ratio (CVR) began with creating a questionnaire for each question with a closed questionnaire on a Likert scale. This method was used to measure agreement between expert panelists on the importance of the item. Expert panelists were given choices for each attribute item offered with three choices, namely (1) important, (2) useful but not important, (3) not important. If more than half of the panelists consider that the quality attribute is important, then the quality attribute has a good content validity ratio [21]. In this study, the quality attribute was considered invalid if it had a CVR value of less than 0.5 . If the quality attribute had a value of $\geq 0.60$, then the attribute was declared important.

The next stage was measuring the validity and reliability of the questionnaire. The validity test utilized the Pearson Correlation method (Pearson Product moment) with the help of the SPSS 14.0 program. This method correlated the score of each item with the total score. The decision making whether the data were valid or not was done by comparing the calculated $r$-value (the value obtained from the calculation of the Pearson correlation method) with the product-moment $\mathrm{r}$ table. A validity coefficient of more than 0.3 was considered satisfactory and has made a good contribution to the efficiency of a research object. To measure the reliability, the Cronbach Alpha method was used with the SPSS statistic 14.0.

Further was the identification of the Quality Attributes of Consumer Needs. The determination of the importance of attributes and attribute weights prioritizes the development of quality attributes required by consumers. This stage was implemented by distributing closed questionnaires with a Likert scale. Consumers were asked to rate each spaghetti quality attribute with a value of 1 (very insignificant), 2 (insignificant), (3 significant), and 4 (very significant). The sampling technique was carried out with nonprobability purposive sampling. The sampling technique did not provide equal opportunities for every element or member of the population to be selected as samples. Here, samples were selected with certain considerations. These results illustrated the value measured by evaluating the importance of a product's attribute called the Fishbein evaluation score (ei). This score indicated the attribute value desired by the respondent for a product. The formula for the level of importance and weighting of the attribute quality is presented in equations 1 and 2 .

$$
\begin{aligned}
& \text { Level of importance }=\frac{\text { total score per attribute }}{\text { number of respondents }} \\
& \text { weighting of the attribute quality }=\frac{\text { Level of importance attribute }}{\text { Importance level of the total attribute }}
\end{aligned}
$$

After obtaining the priority quality attributes required by consumers, the next step was determining the product target specifications. The priority of consumer needs was transformed into technical requirements using the Function Analysis System Technique (FAST) diagram [22]. The FAST diagram was used to systematically map product functions and illustrate the relationship between these functions. FAST was organized 
according to a hierarchy of functions. High-level functions were placed on the left, while low-level functions were placed on the right. Benchmarking of competitive spaghetti products and with consideration of the development team was further conducted. The product target specification then became the response in the experimental design.

The next stage was selecting alternative experimental factors in designing the product concept, which was obtained by using the Zero One Concept approach. This approach was chosen to select the best alternative from several alternatives based on several criteria [5]. The stage began with creating a zero one matrix, then continued with an evaluation matrix to obtain the order of the most influential factors. Making the zero one matrix was conducted by assessing each alternative factor of the experiment relative to the priority needs of consumers. The assessment consisted of numbers 0 and 1 , where number 1 indicated that this factor was more important than other factors. The assessment index of each experimental factor was then multiplied by the weight of the consumer criteria and arranged in an evaluation matrix. The results of the evaluation matrix showed the order of the alternative factors that most influenced the established criteria.

\subsubsection{Robust Concept Design with Taguchi Method}

At this stage, the experimental design of the Taguchi method was proposed for designing the product concept. The experimental factors and levels selected from the zero one and evaluation matrices were used as standard orthogonal matrices. The choice of a standard orthogonal matrix was adjusted according to the number of trial levels. The orthogonal matrix consisted of 3 levels, including L9 (34), L27 (313), L81 (340) [6] [23]. The orthogonal matrix formula in the experimental design is presented in equation (3).

To choose an orthogonal matrix standard of the same level, it was deemed necessary to determine the degrees of freedom. The determination of the degree of freedom is formulated in equation (4). The chosen orthogonal matrix was a standard orthogonal matrix in which degrees of freedom were equal to or greater than the experimental degrees of freedom,

$$
\begin{aligned}
& \operatorname{Lm}\left(x^{k}\right) \\
& \text { degrees of freedom }=(k \times(x-1))+1
\end{aligned}
$$

where :

$L \quad:$ shows information in the form of an orthogonal matrix

$m \quad$ : indicates the number of trials required

$x \quad$ : projects the number of levels used

$k \quad$ : exposes the number of factors used

\subsection{Data Collection}

The identification of consumer preferences was carried out in one of the major cities in Indonesia, namely Bandung, in October - December 2017. The reason for sampling in Bandung was that most spaghetti product consumers are in big cities. Hence, access to get products is easier. Data were collected from children to adults in the city of Bandung with an age range of 10-44 years. The total population was $1,482,389$ people. In calculating the number of samples, the researchers used an error of $10 \%$ to obtain the number of respondents, 100 people. Five expert panelists were involved in assessing the content validity ratio. 


\section{Results and Discussion}

\subsection{Results of Identification of Quality Attributes of Consumer Needs}

This section describes the Identification of Quality Attributes of Consumer Needs. Before the questionnaire was distributed to respondents, a Content Validity Ratio (CVR) was assessed. CVR measured agreement between the assessors and expert panelists on the importance of the item [21].

Table 1. CVR Calculation of Gluten Free Spaghetti Quality Attributes

\begin{tabular}{lcc}
\hline Quality Attributes & CVR Scores & Decision \\
\hline Thickness & 0.60 & Valid \\
Length & 0.00 & Not Valid \\
Taste & 0.80 & Valid \\
Color & 0.60 & Valid \\
Chewiness & 1.00 & Valid \\
Non-stickiness & 0.80 & Valid \\
Hardness & 0.60 & Valid \\
Cooking loss & 0.60 & Valid \\
Cooking time & 0.60 & Valid \\
Nutrition & 1.00 & Valid \\
Local ingredients & 1.00 & Valid \\
Product display & 0.80 & Valid \\
Product weight & 0.20 & Not Valid \\
Price & 1.00 & Valid
\end{tabular}

From the results of filling out the questionnaire, 12 attributes were considered valid and two quality attributes were considered invalid (see Table 1). The quality attribute was considered invalid because it had a CVR value of less than 0.5 . In contrast, the other quality attributes had a value of $\geq 0.60$ and were declared important. The quality attribute that had the highest CVR value for spaghetti products was in terms of the nutritional content of the product, with a CVR value of 1.00 . The nutritional content of spaghetti products was considered the most critical quality attribute in product design. Invalid quality attributes were not included in the questionnaire, distributed to selected consumers/respondents.

The next stage was to test the validity and reliability of the questionnaire, which would be distributed to selected consumers/respondents. The validity and reliability test of the quality attributes of the questionnaire question items is presented in Table 2 . These results indicated that all the quality attributes asked in the questionnaire were valid and reliable. It was indicated by the value of the correlation coefficient, which was higher than the $r$ table. The alpha coefficient value was also higher than the t table.

The results of the priority needs for consumption can be seen in Table 3. Of all the quality attributes, respondents considered that the physical appearance of spaghetti was a quality priority which was considered the most important in designing the spaghetti concept. The results of this study are in line with the research on the manufacture of gluten-free spaghetti pasta from rice flour [16]. The research explained that the quality of the spaghetti product that was wanted to be achieved was good physical quality and nutritional content that met the required spaghetti product standards. The appearance of spaghetti products includes the quality of cooking and the texture of the spaghetti product. The quality of cooking includes cooking time, cooking loss, and cooking weight. Spaghetti's 
textural properties include hardness, adhesiveness, and resilience of the product when drawn [16] [24]. Consumers want spaghetti whose product surface is not sticky, not easily brittle, and with low cooking loss. The results of the identification of quality attributes of customer needs were then translated into technical requirements.

Table 2. Test the Validity and Reliability of the Quality Attributes of the Questionnaire Items

\begin{tabular}{lccc}
\hline Quality attributes & $\begin{array}{c}\text { Correlation } \\
\text { coefficient }\end{array}$ & $\begin{array}{c}\text { Alpha } \\
\text { coefficient }\end{array}$ & Decision \\
\hline Thick & 0.282 & 0.738 & Valid and reliable \\
Taste & 0.242 & 0.738 & Valid and reliable \\
Color & 0.533 & 0.713 & Valid and reliable \\
Chewy & 0.458 & 0.719 & Valid and reliable \\
Sticky & 0.302 & 0.754 & Valid and reliable \\
Hard & 0.339 & 0.760 & Valid and reliable \\
Cooking loss & 0.607 & 0.716 & Valid and reliable \\
Cooking time & 0.605 & 0.710 & Valid and reliable \\
Nutritious & 0.531 & 0.720 & Valid and reliable \\
Local ingredients & 0.594 & 0.707 & Valid and reliable \\
Product/physical appearance & 0.406 & 0.731 & Valid and reliable \\
Price & 0.397 & 0.730 & Valid and reliable \\
\hline
\end{tabular}

Table 3. Five Priorities of Consumer Needs for Spaghetti Products

$\begin{array}{lccc}\text { Quality Attributes } & \text { Significance Level } & \text { Weigh } & \text { Priority level- } \\ \text { Product/physical Appearance } & 3.74 & 0.081 & 1 \\ \text { Nutrition } & 3.67 & 0.080 & 2 \\ \text { Taste } & 3.58 & 0.078 & 3 \\ \text { Price } & 3.40 & 0.074 & 4 \\ \text { Local Ingredients } & 3.39 & 0.074 & 5\end{array}$

\subsection{Establishment of Gluten-Free Spaghetti Technical Requirements}

The next stage was the elaboration of the quality attributes of consumer needs to become technical product requirements using the FAST diagram. The Gluten-Free Spaghetti FAST diagram is presented in Fig. 1. Technical requirements were used to define how the product was able to meet consumer needs. From the FAST diagram, the technical requirements for gluten-free spaghetti products are obtained and then presented in Table 4.

The technical requirements for gluten-free spaghetti products include; (1) the product has a long shelf life with a low percentage of moisture content, (2) the natural color of the material is yellowish-white, (3) the product is not easy to break and is not brittle with a high percentage of elongation, (4) a low percentage of cooking loss, (5) low level of hardness and stickiness, (6) protein and fat contents that meet spaghetti Indonesian National Standards, (7) acceptable taste sensory, (8) and competitive selling price with other competitive products. This is in line with the research of making spaghetti from mocaf flour, corn flour, rice flour, and soybean flour, where the selected products have the lowest cooking loss and contain protein that meets the standards [18]. To determine the product target specifications developed, the next step was benchmarking the competitive products based on the quality criteria for technical product requirements. 


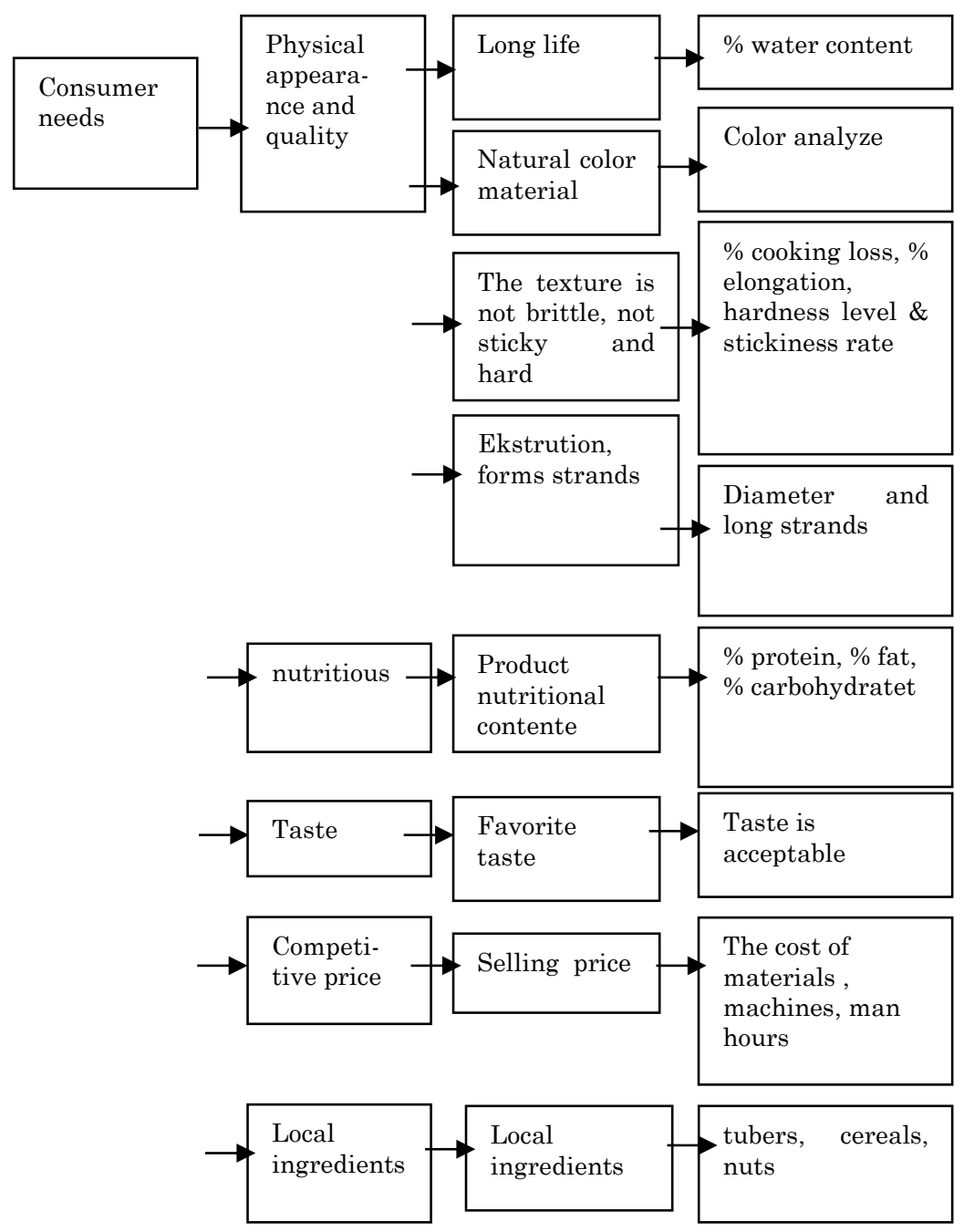

Fig. 1. Gluten-Free Spaghetti FAST Diagram

Table 4. Technical Requirements for Gluten-Free Spaghetti Product Development

Consumer Needs of Spaghetti

Physical Appearance

Nutrition

Taste

Price

Local Ingredients Technical Requirements

\% Water content; Color test; \% Elongation; \% Cooking loss; Hardness level (gf); Stickiness rate $(\mathrm{g} / \mathrm{sec})$

$\%$ Protein content, $\%$ fat content, $\%$ carbohydrate content

The sensory taste test is acceptable to consumers

Competitive selling price

Tubers, nuts, seeds

From the competitive product benchmarking, it is expected that the products developed will be able to compete in the market. Competitive product benchmarking was done by describing and analyzing the nutrition of 5 competitive spaghetti products to determine the range of values of each product development target specification for gluten- 
free spaghetti. Benchmarking analysis results of competitive products and the target specifications for gluten-free spaghetti products can be seen in Table 5.

Table 5. Competitive Product Benchmarking and Gluten-Free Spaghetti Product Target Specification

$\begin{array}{lcc}\text { Technical Requirements } & \begin{array}{c}\text { Benchmarking Result } \\ \text { Quality Analysis }\end{array} & \text { Target Specifications } \\ \text { Water content (\%) } & 8.9-10.75 & <12.5 \\ \text { Color (dL) } & 71.71-79.41 & 72 \\ \text { Elongation (\%) } & 118.237-245.1 & 220 \\ \text { Cooking loss (\%) } & 4.26-11.72 & 11 \\ \text { Hardness (gf) } & 2200-10904 & 2200 \\ \text { Stickiness (g/sec) } & -19.45-64.52 & -35 \\ \text { Protein Content (\%) } & 9.11-18.62 & 12 \\ \text { Fat Content (\%) } & 0.02-1.66 & 1.2 \\ \text { Carbohydrate Content (\%) } & 73.25-82.38 & \text { High } \\ \text { Taste Sensory } & 4-6 & 4 \text { (acceptable) }\end{array}$

From the results of the quality analysis of the five spaghetti products, the lowest to highest values were obtained. The results showed that the target specifications had met the quality analysis of the benchmarking results. The water content of the spaghetti product to be achieved was less than 12.5\% based on SNI 01-4454-1998 regarding the quality requirements of wheat spaghetti. The dL color test value was 72 based on the highest benchmark value of spaghetti color on the market; $220 \%$ elongation based on wheat spaghetti elongation, 2200 gf hardness based on the lowest benchmark value and stickiness $-35 \mathrm{~g} / \mathrm{sec}$ based on the stickiness of spaghetti wheat, $12 \%$ protein content and content $1.2 \%$ fat according to the USDA commercial pasta product standard [25]. The higher the carbohydrate content, the better. The taste acceptance of the organoleptic test was acceptable, and it was made from gluten-free local flour.

\subsection{Selection of Alternative Experiment Factors}

The selection of the most influential experimental factors for designing a glutenfree spaghetti product concept was to use the zero one matrix. The zero one matrix was utilized based on each criterion of consumer needs in the development of gluten-free spaghetti products. The priority criteria for consumer needs from the research results were known to consist of 5, namely: 1st criterion good physical appearance, 2 nd criterion nutritious, 3rd criterion taste, 4th criterion price, and 5th criterion made of local ingredients. Meanwhile, the experimental factors obtained six factors that affect the quality of gluten-free spaghetti, namely: 1st factor (composition of mocaf flour and corn flour) [10]; 2nd factor (level of fineness of flour) [26]; Factor 3 (local ingredients composition to increase protein content) [14]; 4th factor (water content of the dough); The 5 th factor (addition of guar gum); The 6th factor (addition of salt). Each factor was assessed based on the importance of these factors against the criteria required by consumers. From each criterion of customer needs, the index of each factor was obtained. The Zero One Concept Matrix Experimental Factors on the Criteria for Consumer Needs compared to the Spaghetti Display (physical quality) is presented in Table 6. 
Table 6. Zero One Concept Matrix Experiment Factors Against Consumer Needs Criteria: Display Spaghetti (physical quality)

\begin{tabular}{ccccccccc}
\hline Factor $\backslash$ Factor to- & 1 & 2 & 3 & 4 & 5 & 6 & Total & Index \\
\hline 1 & $\mathrm{X}$ & 0 & 1 & 0 & 1 & 1 & 4 & 0.27 \\
2 & 1 & $\mathrm{X}$ & 1 & 1 & 1 & 1 & 5 & 0.33 \\
3 & 0 & 0 & $\mathrm{X}$ & 1 & 1 & 1 & 3 & 0.20 \\
4 & 0 & 0 & 0 & $\mathrm{X}$ & 0 & 1 & 1 & 0.07 \\
5 & 0 & 0 & 0 & 1 & $\mathrm{X}$ & 1 & 2 & 0.13 \\
6 & 0 & 0 & 0 & 0 & 0 & $\mathrm{X}$ & 0 & 0.00 \\
\hline
\end{tabular}

From each criterion of consumer needs, an index of each factor was obtained. The index for each factor was then multiplied by the weight of each consumer criterion. The weight of the 1st consumer criteria for product display was 20.93; the weight of the second consumer criteria, namely nutrition was 20.67 ; the weight of the 3 rd consumer criteria, namely the taste was 20.16; the weight of the 4th criterion that was the price was 19.12 and the weight of the 5 th criterion that was local ingredients was 19.2. The results of the calculations can be seen in the evaluation matrix of each factor against the five consumer criteria in Table 7.

Table 7. Zero One Concept and Evaluation Matrix of Control Factor Priority Selection

\begin{tabular}{|c|c|c|c|c|c|c|c|}
\hline \multirow{3}{*}{$\begin{array}{l}\text { Experiment Factor / } \\
\text { Consumer Needs } \\
\text { Weight }\end{array}$} & \multicolumn{5}{|c|}{ Consumer Needs Criteria } & \multirow{3}{*}{ Total } & \multirow[t]{3}{*}{ Rank } \\
\hline & $\begin{array}{l}\text { Product } \\
\text { Display }\end{array}$ & $\begin{array}{l}\text { Nutriti } \\
\text { on }\end{array}$ & Taste & Price & $\begin{array}{l}\text { Local } \\
\text { Ingredi } \\
\text { ents }\end{array}$ & & \\
\hline & 20.93 & 20.67 & 20.16 & 19.12 & 19.12 & & \\
\hline Flour fineness & 0.27 & 0.27 & 0.33 & 0.33 & 0.20 & 28.01 & 1 \\
\hline Source of Carbohydrates & 0.33 & 0.20 & 0.27 & 0.27 & 0.33 & 27.96 & 2 \\
\hline Source of Protein & 0.20 & 0.33 & 0.13 & 0.13 & 0.27 & 21.41 & 3 \\
\hline Water Addition & 0.07 & 0.07 & 0.00 & 0.00 & 0.00 & 2.77 & 6 \\
\hline Guar gum concentration & 0.13 & 0.13 & 0.07 & 0.07 & 0.13 & 10.72 & 4 \\
\hline Salt concentration & 0.00 & 0.00 & 0.20 & 0.20 & 0.67 & 9.13 & 5 \\
\hline
\end{tabular}

The results of the evaluation of the control factor priority selection can be seen in Table 7. It is suggested that the most influential experimental factors are: the 1st experimental factor, namely the level of fineness of the flour with an evaluation value of 28.01. The last priority factor is the addition of water with an evaluation value of 2.77. The experimental factors chosen in this study were the four most influential factors from the evaluation matrix, including 1) the level of fineness of the flour; 2) the composition of the source of carbohydrates; 3) composition of protein source material, and 4) guar gum concentration.

The first experimental factor, the level of flour fineness, was the most influential factor in the spaghetti product's quality. The smaller the particle size of the flour used or the higher the fineness of the flour, the more fragile the starch granules will rupture so that the strands of the product become stronger. The level of fineness of the flour used consisted of 3 levels, namely 40 mesh, 60 mesh, and 80 mesh. The second experimental factor was the composition of the carbohydrate content (mocaf flour: corn flour) which 
consisted of 3 levels, 35\%: 25\%; 30\%: 30\%; and 25\%: 35\%. These ratios were used because the amylose content in the flour composition played a role in the quality of the noodles. Amylose that has previously emerged from the starch granule (but is still trapped in the flour granule) can spread throughout the dough and form a solid matrix structure via hydrogen bonding during retro-gradation. The gelatinization profile of the raw material has generated an effect on the quality of the noodles. The third experimental factor was the composition of the protein source material (rice flour: soybeans), which consisted of 3 levels, 35\%: 5\%; 30\%: 10\%; and 25\%: $15 \%$. It was confirmed that soy flour could increase the protein content in spaghetti [26]. The addition of soy flour in the manufacture of gluten-free spaghetti can increase protein. However, cooking loss and stickiness would certainly increase [11]. The fourth experimental factor was the guar gum concentration, which consisted of $3 \%, 1 \%, 1.5 \%$, and $2 \%$. It was carried out since the addition of guar gum can increase elongation and reduce hardness and cooking loss.

\subsection{Designing a Robust Product Concept with Taguchi}

The design of the gluten-free spaghetti product concept using the Taguchi method implemented an orthogonal matrix. The orthogonal matrix designed for four experimental factors and three levels was called L9 (34) (Taguchi method). The choice of the orthogonal matrix was based on the calculation of the total degrees of freedom of 9 , so that it used the orthogonal matrix standard L9 (34), which means that the number of experiments/product concepts was 9 . In the standard orthogonal matrix, an experimental design consisting of a combination of factors and levels was provided.

Table 8. Robust Product Concept Design with Taguchi

\begin{tabular}{ccccc}
\hline Concept & Flour Mesh & $\begin{array}{c}\text { Compotition } \\
\text { Mocaf flour : Corn } \\
\text { flour (\%) }\end{array}$ & $\begin{array}{c}\text { Compotition } \\
\text { Rice flour : Soy } \\
\text { flour (\%) }\end{array}$ & Guar gum (\%) \\
\hline 1 & 40 & $35: 25$ & $35: 5$ & 1 \\
2 & 40 & $30: 30$ & $30: 10$ & 1.5 \\
3 & 40 & $25: 35$ & $25: 15$ & 2 \\
4 & 60 & $35: 25$ & $30: 10$ & 1.5 \\
5 & 60 & $30: 30$ & $25: 15$ & 1 \\
6 & 60 & $25: 35$ & $35: 5$ & 1.5 \\
7 & 80 & $35: 25$ & $25: 15$ & 2 \\
8 & 80 & $30: 30$ & $35: 5$ & 1 \\
9 & 80 & $25: 35$ & $: 10$ & \\
\hline
\end{tabular}

There are 9 product concept designs with a combination of factors and levels. Based on the optimization research of Taguchi gluten-free spaghetti, the best concept is the 4 th concept, where gluten-free spaghetti made from local flour (60 mesh) has a composition of $35 \%$ mocaf flour, $25 \%$ corn flour, $30 \%$ rice flour, $10 \%$ soy flour, $1.5 \%$ guar gum, $1 \%$ salt, and $40 \%$ flour-based water. The gluten-free spaghetti produced has met the product target specifications, and its quality has been confirmed, namely with a maximum moisture content of $12.5 \%$; minimum protein content of $9.11 \%$; maximum fat content of $1.66 \%$; carbohydrates minimum $73.25 \%$, maximum cooking time 14 minutes; maximum cooking loss $11.72 \%$; maximum elongation $245.1 \%$; maximum hardness of 4875.22 gf; maximum stickiness -64.52 g.sec; maximum color test 79.41; minimum orlep score of 4 (average) and cheapest material cost [27]. 


\section{Conclusion}

Based on the design concept of a robust gluten-free spaghetti product using the Taguchi method, nine concepts were obtained. The selection of experimental factors considered the quality attributes of consumer needs. The product concept design was combined four factors and three plotting levels resulting in the L9 orthogonal matrix (34). The product concept design was compiled from the identification of consumer needs to the design of the product concept using the Taguchi optimization method. The selected product concept design was the 4th concept and produced gluten-free spaghetti of confirmed quality and met the targeted product specifications. Suggestions for further research are to use more than four experimental factors so that the orthogonal matrix used is different and maximized product quality.

\section{References}

[1] P. Detchewa, M. Thongngam, J.-L. Jane, and O. Naivikul, "Preparation of glutenfree rice spaghetti with soy protein isolate using twin-screw extrusion," Journal of Food Science and Technology, vol. 53, pp. 3485-3494, 2016. https://doi.org/10.1007/s13197-016-2323-8.

[2] D. P. Andriani, M. Choiri, and D. Priharseno, "Aplikasi Quality Function Deployment Untuk Redesign Kontainer Penyimpanan Pada Industri Kemasan Kaleng," Jurnal Teknik Industri, vol. 18, pp. 176-190, 2017. https://doi.org/10.22219/JTIUMM.Vol18.No2.176-190.

[3] K. T. Ulrich, Product design and development: Tata McGraw-Hill Education, 2003.

[4] L. Sularto, Wardoyo, and T. Yunitasari, "User Requirements Analysis for Restaurant POS and Accounting Application Using Quality Function Deployment," Procedia - Social and Behavioral Sciences, vol. 169, pp. 266-280, 2015. https://doi.org/10.1016/j.sbspro.2015.01.310.

[5] T. Pujianto, R. Kastaman, and I. A. Utami, "Penerapan rekayasa nilai dalam pemilihan rancangan kemasan dan rasa produk dodol berdasar pada ketertarikan konsumen," in Proceeding Seminar Nasional Peningkatan Kapabilitas UMKM dalam Mewujudkan UMKM Naik Kelas, 2016, pp. 215-226.

[6] Y. Ekawati and A. A. Hapsari, "Taguchi experimental design to determine the taste quality characteristic of candied carrot," IOP Conference Series: Materials Science and Engineering, vol. 319, p. 012050, 2018. https://doi.org/10.1088/1757899x/319/1/012050.

[7] A. Marti, K. Seetharaman, and M. A. Pagani, "Rheological Approaches Suitable for Investigating Starch and Protein Properties Related to Cooking Quality of Durum Wheat Pasta," Journal of Food Quality, vol. 36, pp. 133-138, 2013. https://doi.org/10.1111/jfq.12015.

[8] M. J. Sissons, N. P. Ames, R. A. Hare, and J. M. Clarke, "Relationship between glutenin subunit composition and gluten strength measurements in durum wheat," Journal of the Science of Food and Agriculture, vol. 85, pp. 2445-2452, 2005. https://doi.org/10.1002/jsfa.2272.

[9] Y. A. Merayo, R. J. González, S. R. Drago, R. L. Torres, and D. M. De Greef, "Extrusion conditions and zea mays endosperm hardness affecting gluten-free spaghetti quality," International Journal of Food Science \& Technology, vol. 46, pp. 2321-2328, 2011. https://doi.org/10.1111/j.1365-2621.2011.02752.x.

[10] N. K. I. Mayasti, M. Ushada, and M. Ainuri, "Analisis Mutu Produk Spaghetti Komersil dan Pengembangan Produk Spaghetti Berbasis Tepung Beras, Jagung, 
Mocaf, Kedelai," Jurnal Pangan, vol. 27, pp. 129-140, 2018. https://doi.org/10.33964/jp.v27i2.373.

[11] C. Bruneel, B. Pareyt, K. Brijs, and J. A. Delcour, "The impact of the protein network on the pasting and cooking properties of dry pasta products," Food $\begin{array}{lllll}\text { Chemistry, } & \text { vol. } & 120, & \text { pp. } & 371-378,\end{array}$ https://doi.org/10.1016/j.foodchem.2009.09.069.

[12] H.-H. Chen, C.-C. Chung, H.-Y. Wang, and T.-C. Huang, "Application of Taguchi method to optimize extracted ginger oil in different drying conditions," in IPCBEE May, 2011, pp. 310-316.

[13] M. A. Giménez, R. J. González, J. Wagner, R. Torres, M. O. Lobo, and N. C. Samman, "Effect of extrusion conditions on physicochemical and sensorial properties of corn-broad beans (Vicia faba) spaghetti type pasta," Food Chemistry, vol. 136, pp. 538-545, 2013. https://doi.org/10.1016/j.foodchem.2012.08.068.

[14] A. B. do Nascimento, G. M. R. Fiates, A. dos Anjos, and E. Teixeira, "Analysis of ingredient lists of commercially available gluten-free and gluten-containing food products using the text mining technique," International Journal of Food Sciences $\begin{array}{lllll}\text { and Nutrition, } & \text { vol. } 64, & 217-222,\end{array}$ https://doi.org/10.3109/09637486.2012.718744.

[15] S. Chillo, J. Laverse, P. M. Falcone, and M. A. Del Nobile, "Effect of carboxymethylcellulose and pregelatinized corn starch on the quality of amaranthus spaghetti," Journal of Food Engineering, vol. 83, pp. 492-500, 2007. https://doi.org/10.1016/j.jfoodeng.2007.03.037.

[16] L. Padalino, A. Conte, and M. A. Del Nobile, "Overview on the General Approaches to Improve Gluten-Free Pasta and Bread," Foods, vol. 5, pp. 1-18, 2016. https://doi.org/10.3390/foods5040087.

[17] C. S. Raina, S. Singh, A. S. Bawa, and D. C. Saxena, "Textural Characteristics of Pasta Made From Rice Flour Supplemented With Proteins And Hydrocolloids," Journal of Texture Studies, vol. 36, pp. 402-420, 2005. https://doi.org/10.1111/j.1745-4603.2005.00024.x.

[18] N. K. I. Mayasti, M. Ushada, and M. Ainuri, "Improvement of Spaghetti composite quality based on local flours (mocaf, corn, rice and soybean)," in AIP Conference Proceedings, 2019, p. 020063. https://doi.org/10.1063/1.5134627.

[19] D. Anggraini, S. K. Dewi, and T. E. Saputro, "Aplikasi Metode Taguchi Untuk Menurunkan Tingkat Kecacatan Pada Produk Paving," Jurnal Teknik Industri, vol. 16, pp. 1-9, 2017. https://doi.org/10.22219/JTIUMM.Vol16.No1.1-9.

[20] G. J. Besseris, "Profiling multiple static and transient puff-pastry characteristics with a robust-and-intelligent processor," Journal of Food Engineering, vol. 164, pp. 40-54, 2015. https://doi.org/10.1016/j.jfoodeng.2015.04.011.

[21] C. H. Lawshe, "A quantitative approach to content validity," Personnel psychology, vol. 28, pp. 563-575, 1975.

[22] B. Di Fabio and M. Ferri, "Comparing persistence diagrams through complex vectors," in International Conference on Image Analysis and Processing, 2015, pp. 294-305. https://doi.org/10.1007/978-3-319-23231-7_27.

[23] S. D. Bolboacă and L. Jäntschi, "Design of Experiments: Useful Orthogonal Arrays for Number of Experiments from 4 to 16," Entropy, vol. 9, pp. 198-232, 2007. https://doi.org/10.3390/e9040198.

[24] P. Sereewat, C. Suthipinittham, S. Sumathaluk, C. Puttanlek, D. Uttapap, and V. Rungsardthong, "Cooking properties and sensory acceptability of spaghetti made from rice flour and defatted soy flour," LWT - Food Science and Technology, vol. 60, pp. 1061-1067, 2015. https://doi.org/10.1016/j.lwt.2014.10.001. 
[25] S. A. El-Sohaimy, M. Brennan, A. M. G. Darwish, and C. Brennan, "Physicochemical, texture and sensorial evaluation of pasta enriched with chickpea flour and protein isolate," Annals of Agricultural Sciences, vol. 65, pp. 28-34, 2020. https://doi.org/10.1016/j.aoas.2020.05.005.

[26] J. S. Chen, M. J. Fei, C. L. Shi, J. C. Tian, C. L. Sun, H. Zhang, et al., "Effect of particle size and addition level of wheat bran on quality of dry white Chinese noodles," Journal of Cereal Science, vol. 53, pp. 217-224, 2011. https://doi.org/10.1016/j.jcs.2010.12.005.

[27] N. K. I. Mayasti, M. Ushada, and M. Ainuri, "Optimization of Gluten Free Spaghetti Products from Local Food with the Taguchi Method Approach," in IOP Conference Series: Earth and Environmental Science, 2019, p. 012031. https://doi.org/10.1088/1755-1315/251/1/012031. 